\title{
Trypanorhynch cestodes from Indonesian coastal waters (East Indian Ocean)
}

\author{
Harry W. Palm
}

Institut für Zoomorphologie, Zellbiologie und Parasitologie, Heinrich-Heine-Universität Düsseldorf, Universitätsstraße 1, D-40225 Düsseldorf, Germany

Key words: Trypanorhyncha, taxonomy, Dasyrhynchus, Otobothrium, Nybelinia, Sphyriocephalus, Tentacularia, ultrastructure, sensory receptor, Indonesia, zoogeography

\begin{abstract}
Results of a study on trypanorhynch cestodes of fishes from Indonesian coastal waters are presented. A new species, Dasyrhynchus thomasi sp. n., is described, and five species are recorded which all represent new locality records: Tentacularia coryphaenae Bosc, 1797; Nybelinia africana Dollfus, 1960; Nybelinia scoliodoni (Vijayalakshmi, Vijayalakshmi et Gangadharam, 1996); Sphyriocephalus dollfusi Bussieras et Aldrin, 1968; and Otobothrium penetrans Linton, 1907. Their known ranges of distribution are extended to the East-Indian Ocean. Scanning and transmission electron microscopy was used to clarify details of the tentacular armature and surface morphology of $T$. coryphaenae, D. thomasi and O. penetrans. In T. coryphaenae, hook-like microtriches along the bothridial tegument are embedded in the distal cytoplasm, sometimes showing a split base. The solid tentacular hooks are embedded into a fibrillar, highly ordered tentacular wall. D. thomasi is distinguished by its characteristically shaped bothridia and a triple chainette with winged hooks on the external surface of the tentacle. Tufts of microtriches with ciliated sensory receptors are regularly arranged on the bothridial surface of $O$. penetrans. They show similarities to sensory receptors reported from other trypanorhynch cestodes. Otobothrium pephrikos Dollfus, 1969 is considered a junior synonym for $O$. penetrans, and the variability of the scolex within trypanorhynch cestodes is emphasised.
\end{abstract}

With a coastline of about $81,000 \mathrm{~km}$, Indonesia has one of the largest coastal zones in the world. Over 2,500 different marine fish species have been described from Indonesian marine waters (Froese et al. 1996). This species-rich fish fauna is still underexploited as a major food resource, and consequently investigations of aspects of marine fish hygiene are still rudimentary.

Between 1952-1954, Yamaguti carried out a largescale study on fish parasites from Indonesian coastal waters, from the Celebes and adjacent waters. The author focused on metazoan parasites, trematodes (1952, 1953a), monogeneans (1953b), nematodes (1954a), acanthocephalans (1954b), and crustaceans (1954c). Yamaguti (1954d) recorded five cestode species, with a single trypanorhynch Hornelliella annandalei (Hornell, 1912) from the waters off Macassar. In 1978, several fish species were examined for the presence of anisakid nematodes (Hadidjaja et al. 1978, Hutomo et al. 1978, Ilahude et al. 1978), which are known to cause anisakiasis in South-East Asian countries (Petersen et al. 1993). However, the knowledge of marine fish parasites in Indonesia is still rudimentary, and Indonesian tropical waters are poorly explored with respect to the zoogeographical distribution of marine fish parasites.

Trypanorhynch cestodes, which mature in elasmobranchs, are frequent and species-rich fish parasites in the tropics. As they use teleost fishes as intermediate or transport hosts, they also may have a negative impact on fishing and the fish processing industry (Arthur et al. 1982). The exploitation of Brama raji Bloch et Schneider from the Northwest African coast and of Thyrsites atun (Euphrasen) from the Cook Strait, New Zealand, is hindered by the presence of Gymnorhynchus gigas Rudolphi, 1819 and Molicola thyrsitae (Robinson, 1959) in the flesh (Mehl 1970, Seyda 1976), respectively, and the presence of Nybelinia surmenicola Okada, 1929 in the muscles of Theragra chalcogramma (Pallas) has forced an adaptation of the fish processing methods (Arthur et al. 1982). In tropical mariculture, trypanorhynch cestodes might also become introduced into commercial net cages, as is known for other parasitic groups (Paperna 1991, Seng 1997). This strengthens the focus also on trypanorhynchs in marine fish from Indonesian coastal waters.

In contrast to well studied regions as the Gulf of Mexico with at least 34 recorded trypanorhynch species (Palm and Overstreet, in press), only two species, Kotorella pronosoma (Stossich, 1901) (off Batavia, Java Sea, see Palm and Walter 1999) and $H$. annandalei, have been previously described from the Indonesian coastal waters. The purpose of the present study is to present further records of trypanorhynchs collected from Indonesia, allowing comments to be made on the zoogeography of some cestode species and giving some indication of the marine cestode fauna off Indonesia. A new species is described and the surface ultrastructure of Tentacularia coryphaenae Bosc, 1797,

Address for correspondence: H.W. Palm, Center for Coastal and Marine Resource Studies, Faculty of Fisheries and Marine Sciences, Bogor Agricultural University, Campus IPB Darmaga, Bogor 16680, Indonesia. Phone: ++62 251 355933; Fax: ++62 251 622907; E-mail: hpalm@gmx.net 
Dasyrhynchus thomasi sp. n. and Otobothrium penetrans Linton, 1907 is examined by scanning and transmission electron microscopy.

\section{MATERIALS AND METHODS}

During August-September 1998, different fish species and the intestine of an unidentified shark were bought in the fish market of the fishing village Pelabuhanratu, West Java, Indonesia. The fish were examined macroscopically for the presence of trypanorhynch cestodes in the body cavity, the viscera and the musculature. A further trypanorhynch species was isolated from the musculature of a flatfish Psettodes erumei (Bloch et Schneider), (Psettodidae) obtained from the fish market of Sibolga, North Sumatra, Indonesia. For comparison, the type specimen of Otobothrium pephrikos Dollfus, 1969 and the lectotype of Dasyrhynchus pillersi Southwell, 1929 were borrowed from the Muséum National d'Histoire Naturelle Paris, slide BD 16, position 83-85, and The Natural History Museum London, 1977.11.14.11, respectively.

The trypanorhynchs obtained from Pelabuhanratu were fixed either in $10 \%$ buffered formalin for light microscopical or $2.5 \%$ glutaraldehyde in phosphate buffer containing $7.5 \%$ sucrose for electron microscopical investigation. The worms from Sibolga were fixed and stored in Bouin's fixative until further examination. Specimens were stained in aceticcarmine, dehydrated, cleared in eugenol and mounted in balsam. To study the tentacular armature and surface ultrastructure, some specimens were dehydrated in an alcohol series, critical point dried with $\mathrm{CO}_{2}$ and mounted with double adhesive tape onto stubs. These stubs were sputter-coated with gold-palladium in an argon atmosphere and examined with a Zeiss DSM SEM at $15 \mathrm{kV}$. For transmission electron microscopy, specimens were fixed in $2.5 \%$ glutaraldehyde in 0.6 M Sörensen's phosphate buffer containing $7.5 \%$ sucrose, rinsed in phosphate buffer, postfixed in $2 \%$ phosphate buffered osmium tetroxide, dehydrated in ethanol and propylene oxide and embedded in Spurr's resin. Ultrathin sections were cut with glass knives on a Reichert Om U3 ultramicrotome, stained with uranyl acetate and lead citrate and examined with a Siemens Elmiskop 101 TEM.

In the taxonomic sections of this communication, the following abbreviations are used for the different body parts of the trypanorhynchs: scolex length (SL), scolex width (SW), pars bothridialis (pbo), pars vaginalis (pv), pars bulbosa $(\mathrm{pb})$, appendix (app), velum (vel) and scolex proportions (SP), with pbo : pv : pb, total hook length (L), hook length of the base (B), hooks per half spiral row (hsr). All measurements are given in micrometres unless otherwise indicated. The range is given in parentheses. The orientation of tentacle surfaces and the classification follows that of Dollfus (1942) and Palm $(1995,1997 a)$, respectively.

\section{RESULTS}

Six trypanorhynch species were collected. Besides the description of Dasyrhynchus thomasi as new species, all represent new locality records. While adults of the tentaculariids Nybelinia africana Dollfus, 1960,
N. scoliodoni (Vijayalakshmi, Vijayalakshmi et Gangadharam, 1996) and Sphyriocephalus dollfusi Bussieras et Aldrin, 1968 were found in the stomach and the intestine of an unidentified shark, Tentacularia coryphaenae occurred in the body cavity of Katsuwonus pelamis (L.), and Otobothrium penetrans and $D$. thomasi infested the flesh of Tylosurus crocodilus (Peron et Lesueur) and Psettodes erumei, respectively. Remarks on the individual species isolated, particularly on their taxonomy, ultrastructure and zoogeography, are presented below.

Superfamily: TENTACULARIOIDEA Poche, 1926

Family: T e n t a c u 1 a ri id a e Poche, 1926

Tentacularia coryphaenae Bosc, $1797 \quad$ Figs. 1-7

Two Katsuwonus pelamis of 51.0 and $58.5 \mathrm{~cm}$ body length harboured 11 and $15 \mathrm{~T}$. coryphaenae in the body cavity, and the latter two specimens in the belly flaps. The specimens were variable in size, however, were within the known range for $T$. coryphaenae, and the characteristic homeoacanthous tentacular armature with three-fingered basal hooks (Fig. 1) was present. The specimens were identified following Dollfus (1942).

The massive tentacular hooks insert into a fibrillar, multilayered and highly ordered tentacular wall (Fig. 2). The hooks contain microfilaments. The surface of $T$. coryphaenae is covered with filamentous microtriches and hook-like microtriches along the bothridial margins (Figs. 3, 4). These hook-like microtriches (Fig. 3) consist of a cortex, surrounding an electron-dense medulla, and a glycocalyx (Fig. 5). They are embedded in the distal cytoplasm (Fig. 4), interspersed with filamentous microtriches. The base of some of these hook-like microtriches is split into two branches of electron-dense material, embedded into the distal cytoplasm (Figs. 5, 6). A junction region with junctional tubule and a basal region are absent. Root-like microfilamentous endings and circular canaliculi appear in the centre of some of these microtriches (Fig. 7).

Remarks: Tentacularia coryphaenae is a cosmopolitan trypanorhynch (for records see Dollfus 1942) and is reported herewith for the first time also from Indonesia. Katsuwonus pelamis is a world-wide migrating teleost and a known host for the species (Lester et al. 1985). This behaviour enables a transfer of oceanic $T$. coryphaenae from or into the coastal waters of Indonesia. T. coryphaenae has been recorded before from adjacent seas such as off Taiwan (Chen and Yang 1973), the Indian Ocean (as Tetrarhynchus sp. in Southwell 1930, Dubina 1985) and along the Australian/New Zealand coast (Lester et al. 1985, Beveridge and Campbell 1996).

The surface ultrastructure of the species has been studied before using scanning electron microscopy. Bilquees and Khurshid (1988) and Palm (1995) 

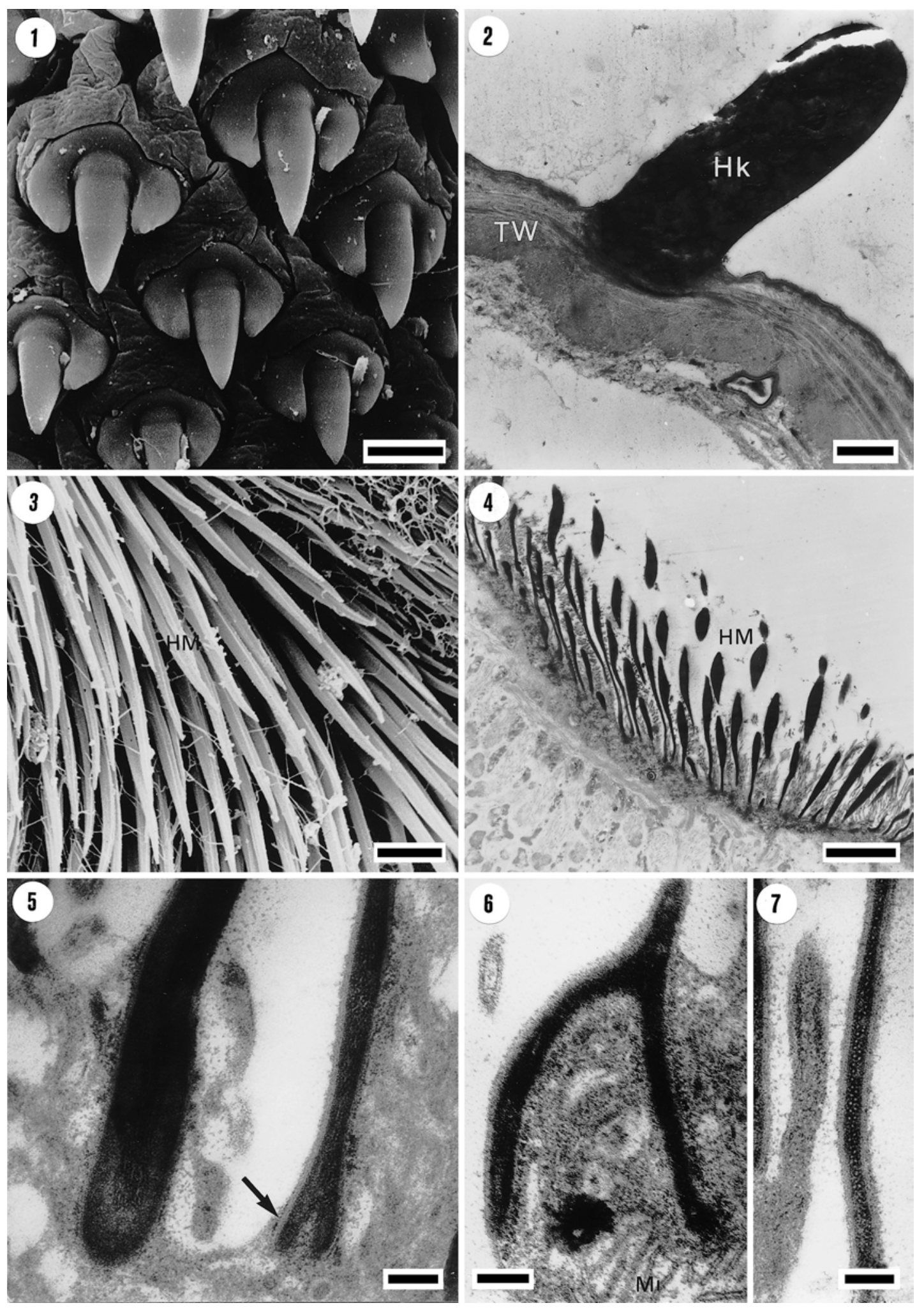

Figs. 1-7. Tentacularia coryphaenae from Katsuwonus pelamis, SEM and TEM of the scolex. Fig. 1. Basal tentacular armature, showing tridigitate hooks. Fig. 2. Massive hook of metabasal armature with multilayered tentacular wall. Figs. 3-4. Hook-like microtriches along the bothridial margins. Note the interspersed filamentous microtriches. Figs. 5-6. Basal part of hook-like microtriches. Note the split base (arrow). Fig. 7. Canaliculi within the hook-like microtriches. Abbreviations: TW - tentacle wall; $\mathrm{Hk}$ - hook; $\mathrm{HM}$ - hook-like microtriches; $\mathrm{Mi}$ - mitochondria. Scale bars: Figs. 1, $2=5 \mu \mathrm{m}$; Fig. $3=3 \mu \mathrm{m} ;$ Fig. $4=2 \mu \mathrm{m}$; Figs. $5-7=100 \mathrm{~nm}$. 
documented the tentacular armature and hook-like microtriches along the bothridial margins (see also Figs. 1, 3). The surface ultrastructure resembles species belonging to Nybelinia Poche, 1926, as described for $N$. alloiotica, N. edwinlintoni, and N. lingualis (see Palm 1995). Jones and Beveridge (1998) demonstrated the surface ultrastructure of $N$. queenslandensis by transmission electron microscopy, and described stout and hook-like microtriches of a similar ultrastructure to that observed in the present specimens. However, the description of split basal endings within these microtriches, which might help to anchor them within the distal cytoplasm, is new.

\section{Nybelinia africana Dollfus, 1960}

Several adults of $N$. africana were found in the stomach of an unidentified shark. The specimens were variable in size. The following measurements were taken for one small and two larger specimens: SL $=$ $735,1265,1435 ;$ pbo $=465,765,1035 ; \mathrm{pv}=320,720$, $850 ; \mathrm{pb}=230,365,455 ; \mathrm{vel}=200,215,165 ; \mathrm{SP}=$ 2.0:1.4:1, 2.1:2:1, 2.3:1.9:1; bulb ratio 2.1-2.4:1, 2.3$2.4: 1,2.6: 1$. Tentacular armature homeomorphous, basal armature of about 5-6 rows with rose-thornshaped hooks $(\mathrm{L}=8.0-14.0 ; \mathrm{B}=6.5-8.0)$. Metabasal armature of slender hooks with a strongly recurved tip (L=19-22; B = 7.0-8.0); hsr = 7-8.

Strobila acraspedote, with proglottids wider than long (up to 780 long $\times 1100$ wide). Testis ovoid, 65-92 in diameter, arranged in a single layer. Due to the macerated condition, no further details could be observed.

Remarks: The specimens were in a macerated condition and during preparation, the worms became very flattened. Thus, a SL of 1435 is at the upper size limit for the species. The morphological characters of the present specimens correspond to those as given by Dollfus (1960) and summarised in Palm (1999). These authors reported a size range between 440-1100 and a scolex and bulb ratio of $2: 1: 1$ and 1.9-3.4:1. The hook size ranged between 9.6-17 and the hsr was 7-8 (Palm 1999). The present specimens lie within the same range with the exception that the metabasal hooks are slightly larger (up to 22). However, the form and arrangement of the tentacular armature corresponds with that described by Dollfus (1942, 1960) and Palm (1999). Palm et al. (1997) described N. africana with a large scolex and tentacular hooks ranging from 10-16 basal and 20-32 metabasal from the coastal waters of Mozambique. The testis number, size (65-92 vs 70-95) and arrangement also correspond with that described by Palm (1999). N. africana has a circum-African distribution and the present finding extends the known range of distribution from the South-East Indian to the South-West Indian Ocean.
Nybelinia scoliodoni (Vijayalakshmi, Vijayalakshmi et Gangadharam, 1996)

Several adults of $N$. scoliodoni were found in the stomach of the unidentified shark. As the specimens were in poor condition (also see $N$. africana), no detailed scolex measurements could be taken. SL $=760$ 900. Hooks were different on basal and metabasal parts of tentacle. Basal, about 14 rows of small and solid hooklets $(\mathrm{L}=5.5-6.5 ; \mathrm{B}=5.8-7.0)$ increasing in size; metabasal, larger and more slender, spiniform hooks $(\mathrm{L}=22.3-23.4 ; \mathrm{B}=8.5-10)$ were evident. The largest proglottids were 560 long and 1000 wide.

Remarks: Though morphometrical data of the scolex could not be taken, the tentacular armature of the present specimens corresponds closely with those described by Vijayalakshmi et al. (1996, fig. 8) and Palm (1999, fig. 17). This is the first record for Nybelinia scoliodoni from the eastern part of the Indian Ocean, indicating a wide distribution for the species.

Family: S p h y r i o c e p ha lid a e Pintner, 1913

\section{Sphyriocephalus dollfusi Bussieras et Aldrin, 1968}

A single adult specimen of $S$. dollfusi was found in the spiral valve of an unidentified shark. The worm (71 $\mathrm{mm}$ total length) had a large scolex (about $11.2 \mathrm{~mm}$ ), not well separated from the following strobila. SW at pbo $=6.95 \mathrm{~mm}$. Pbo $=3.1 \mathrm{~mm}$, oval to round bothridia, $2.8 \times 2.1 \mathrm{~mm} ; \mathrm{pv}=2.9 \mathrm{~mm} ; \mathrm{pb}=3.36 \mathrm{~mm}$, bulb length $=2.1-2.24 \mathrm{~mm}$, bulb width $=865-1175$, bulb ratio $=$ 2:1-2.4:1. Pbo and pb not overlapping. Tentacles evaginated up to $2.2 \mathrm{~mm}, 560$ in diameter, with about 23 rows of rose-thorn-shaped hooks reaching a size of $\mathrm{L}=136, \mathrm{~B}=120$.

Remarks: Dollfus (1942) summarised the information on the genus Sphyriocephalus Pintner, 1913 and redescribed two species, S. tergestinus and $S$. viridis. Bussieras and Aldrin (1968) and Heinz and Dailey (1974) added two further species, S. dollfusi and $S$. pelorosoma, to the genus. $S$. tergestinus differs from the present specimen by having a different scolex form, bulb position and hook size. S. viridis differs by having distinctly smaller hooks, a smaller TW, and a basal tentacular swelling with a characteristic basal armature. In $S$. pelorosoma, the bulb ratio is distinctly higher (6:1) and the large width of the strobila was not observed in the present specimen. The species is identified as $S$. dollfusi by having a similar scolex morphology, tentacular armature and hook size $(\mathrm{L}=$ 136 vs $126-138)$, bulb ratio $(2-2.4: 1$ vs $2.5-3.5: 1)$ as well as tentacle length. The known range of distribution for $S$. dollfusi is extended to the East Indian Ocean. 
Palm: Trypanorhynch cestodes from Indonesia
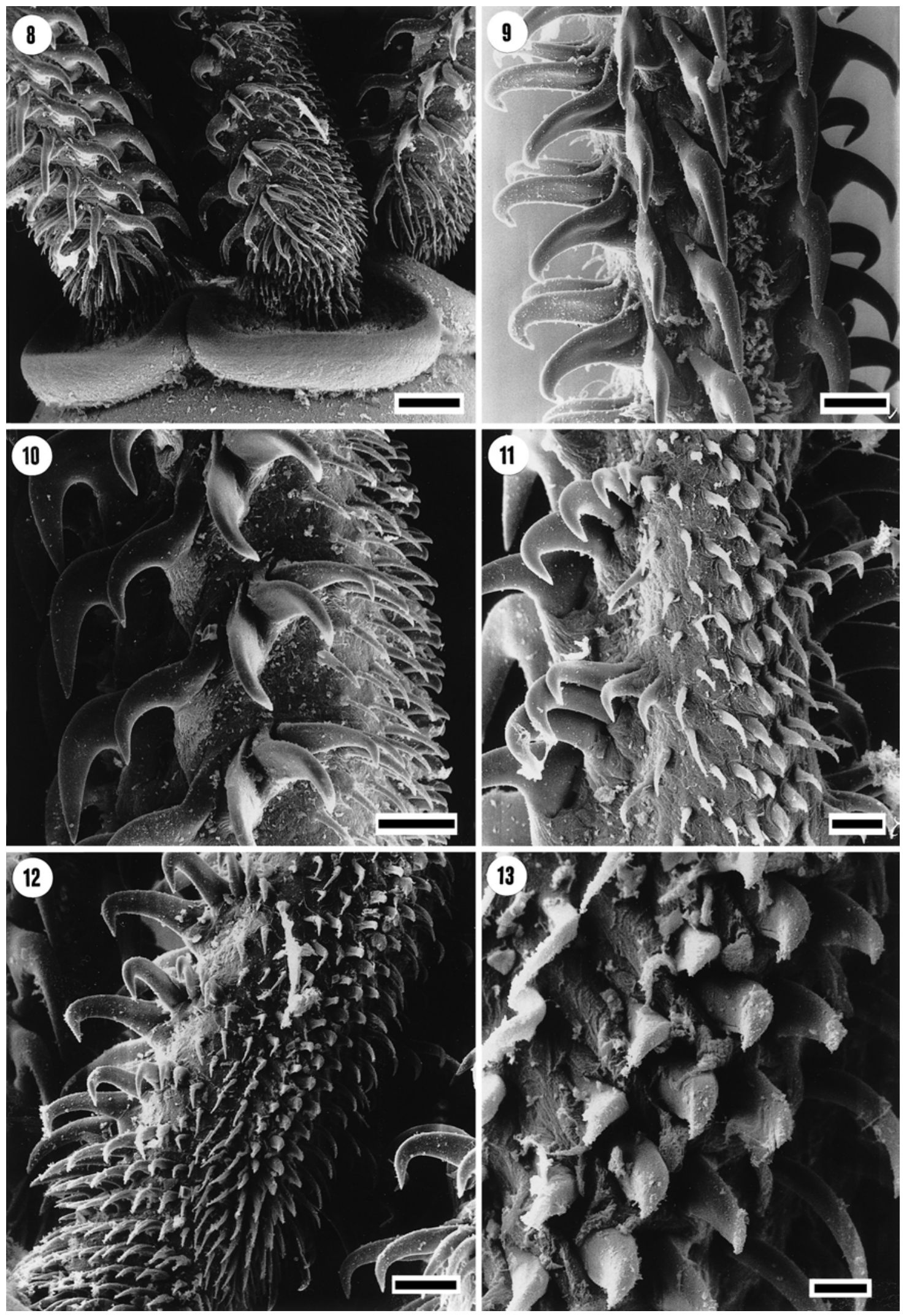

Figs. 8-13. Dasyrhynchus thomasi sp. n. from Psettodes erumei, SEM. Fig. 8. Cordiform bothridia with deep posterior notch and free margins. Fig. 9. Metabasal armature, internal tentacle surface. Fig. 10. Metabasal armature, bothridial tentacle surface. Fig. 11. Metabasal armature, external tentacle surface. Fig. 12. Basal armature, external view. Fig. 13. Triple chainette on external tentacle surface. Scale bars: Fig. $8=100 \mu \mathrm{m}$; Figs. 9, 10, $12=50 \mu \mathrm{m}$; Fig. $11=20 \mu \mathrm{m}$; Fig. $13=10 \mu \mathrm{m}$. 
Family: L a c i s t o r h y n c h i d a e Guiart, 1927

\section{Dasyrhynchus thomasi sp. n.}

Figs. 8-13, 20-23

Description (holotype and paratype): With the characters of the genus Dasyrhynchus: Scolex elongate 14.4, $15.0 \mathrm{~mm}$, widening posteriorly, slightly craspedote (Fig. 20), with thick scolex tegument; pbo short 270, 230; two bothridia, broadly cordiform with deep posterior notch and free margins (Fig. 8); bothridia covered with hexadigitate $1.5 \mu \mathrm{m}$ long microtriches; $\mathrm{pv}$ $=9.7,10.5 \mathrm{~mm}$; sheaths straight in anterior pars vaginalis and sinuous to coiled in remainder; bulbs elongate 3.35 (3.3-3.4), 3.65 (3.6-3.7) $\mathrm{mm}$ long, 345 $(340-350), 345$ (330-370) wide; width/length ratio 1:9.7, 1:10.5; prebulbular organ absent; bulbs project into pars proliferans of scolex; origin of retractor muscle not seen. Tentacles not fully everted, 1.3-1.5 $\mathrm{mm}$ long (Fig. 20); basal swelling absent; diameter at base 135-170, at mid region 200-230. Armature poeciloacanthous (Figs. 8-13, 21-23); hollow hooks arranged in half spiral rows of 9 principal hooks, diminishing in size along row; 3 rows of intercalary hooks present between each principal row, 4 hooks in row 1, 3-4 hooks in row 2, 2-3 hooks in row 3 (Fig. 23). Hooks 1 (1') large, uncinate, 130-160 long, base 100120; 2 (2') elongate, 100-125 long, base 75-90; 3 (3') long and slender, 90-115 long, base 25-35; hooks 4 (4')-7 (7') long, slender, falcate, continuously decreasing in size; 4 (4') 60-80 long, base 15-25; hooks 7 (7') 35-45 long, base 13-20. Hooks 8 (8') and 9 (9') spiniform 35-40 long, base 10-15 (Figs. 11-13, 23); spiniform intercalary hooks, 15-30 long, base 5-10, aligned with hooks $8\left(8^{\prime}\right)$ and $9\left(9^{\prime}\right)$; triple chainette present, with a central massive, more triangular hook, 20-26 long, base 8-10, and 2 hooks with uncinate blade, greatly elongated handle. Characteristic basal armature present (Figs. 12, 23), of spiniform hooks of different size in ascending rows. First row of basal armature consists of claw-like large hooks, followed by smaller triangular hooks; trapezoidal area of prominent uncinate hooks in array approximately $8 \times 8$ hooks present.

$\mathrm{T}$ y $\mathrm{p}$ e $\mathrm{h}$ o s t : Psettodes erumei (Bloch et Schneider), Psettodidae.

$\mathrm{S}$ i t e : musculature.

$\mathrm{T}$ y p e 1 o c a 1 i t y : coastal waters off Sibolga, North Sumatra, Indonesia. 24.01.1991. Collected by R. Thomas.

$\mathrm{T}$ y p e $\mathrm{m}$ a t e r i a 1 : Holotype and paratype in the British Museum (Natural History), London, numbers BM (NH) 1999.9.29.1 and 2000.4.11.1, respectively.

E $\mathrm{t}$ y $\mathrm{m}$ o $1 \mathrm{o} \mathrm{g} \mathrm{y}$ : The new species was named after the collector, R. Thomas, Institut für Meereskunde, Kiel.
Remarks: Dasyrhynchus thomasi is characterised by a poeciloacanthous armature with 9 calary hooks, a triple chainette, and 3 rows of intercalary hooks. Due to its characteristic scolex morphology, one set of chainette elements per principal or intercalary row, and the triple chainette, the new species is assigned to Dasyrhynchus Pintner, 1928. It closely resembles Dasyrhynchus pillersi (Southwell, 1929) (see Beveridge and Campbell 1998). However, a comparison with the lectotype of $D$. pillersi revealed differences in the form of the bothridia (smaller and deeply notched in $D$. thomasi) and in oncotaxy; the form and size of the chainette elements is different, the tentacular hooks are smaller and hooks 2 (2') are distinctly smaller in comparison to hooks 1 ( $\left.1^{\prime}\right)$ in D. thomasi, and the basal armature differs. While the central chainette elements are massive, triangular and clearly differ from the surrounding external hooks, the central chainette in $D$. pillersi is difficult to distinguish from the intercalary and external hooks.

Two other similar species are Dasyrhynchus (=Pseudogilquinia) magnus (Bilqees et Khurshid, 1985) and Pseudogilquinia karachiense Bilquees et Khatoon, 1980. Beveridge and Campbell (1993) re-described $D$. magnus as having 9 principal hooks with a double chainette as well as different scolex measurements. The present species clearly differs by a larger scolex size and a chainette consisting of three elements. $P$. karachiense was described as having distinctly different scolex mea-surements and a tentacular armature consisting of circles of 20 smaller and relatively delicate hooks and 4 large hooks with broad bases (24 in total in contrast to 21 in D. thomasi). However, the description and illustrations are difficult to interpret. The trapezoidal area of prominent uncinate hooks in arrays of approximately $8 \times 8$ hooks as described for D. magnus and P. karachiense was also seen in $D$. thomasi.

Dasyrhynchus indicus Chandra et Hanumantha Rao, 1985 also resembles $D$. thomasi by its similar scolex morphology and a poeciloacanthous armature. The species differs by having a single chainette and 2-3 rows of thin and spiniform hooks arranged in an irregular manner on the external tentacle surface. Beveridge and Campbell (1993) left this species as species inquirenda due to the poor original description and uncertainty of its synonymy with $D$. magnus. Thus, the present specimens represent a new species, Dasyrhynchus thomasi. 

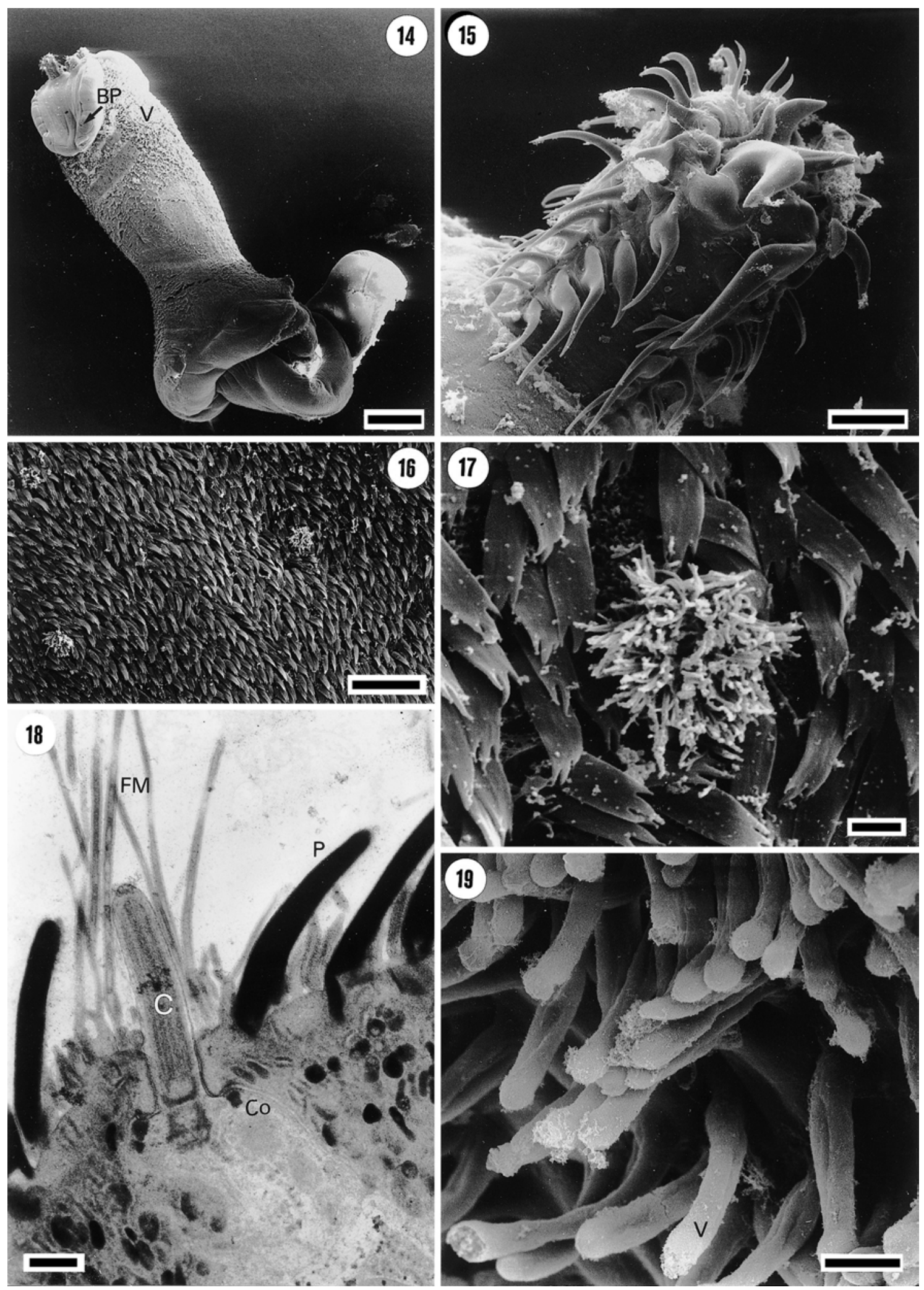

Figs. 14-19. Otobothrium penetrans from Tylosurus crocodilus, SEM and TEM. Fig. 14. Scolex. Fig. 15. Basal armature, internal view. Figs. 16-17. Surface of bothridia with tridigitate microtriches and tufts of filamentous microtriches covering sensory receptors. Fig. 18. Ciliated sensory receptor beneath the tufts of filamentous microtriches. Fig. 19. Microvilli along the pv. Abbreviations: $\mathrm{BP}$ - bothridial pit; $\mathrm{C}$-cilium; Co-collar; $\mathrm{FM}$ - filamentous microtriches; $\mathrm{P}$ - tridigitate microtriche; V - villi. Scale bars: Fig. $14=500 \mu \mathrm{m}$; Fig. $15=50 \mu \mathrm{m}$; Fig. $16=10 \mu \mathrm{m}$; Fig. $17=1 \mu \mathrm{m}$; Fig. $18=300 \mu \mathrm{m}$; Fig. $19=20 \mu \mathrm{m}$. 
Superfamily: ОTOBOTHRIOIDEA Dollfus, 1942

Family: O t o b o th ri id a e Dollfus, 1942

\section{Otobothrium penetrans Linton, $1907 \quad$ Figs. 14-19}

Two of three specimens of Tylosurus crocodilus between $76-90 \mathrm{~cm}$ body length were infected with one and two plerocercoids of $O$. penetrans. The blastocysts were located in the flesh along the vertebral column, similar as indicated by Petersen et al. (1993). The following measurements of the scolex (Fig. 14) were taken: $\mathrm{SL}=6440 ; \mathrm{SW}=2240$ at pbo, 1680 at pv, 3135 at $\mathrm{pb} ; \mathrm{pbo}=1300 ; \mathrm{pv}=2300 ; \mathrm{pb}=1260 ; \mathrm{SP}=1: 1.8: 1$; bulb length $=1365$ (1300-1414), bulb width $=550$ $(500-600)$, bulb ratio $=2.5: 1(2.4: 1-2.8: 1) ;$ app $=2300$. Tentacular armature heteroacanthous atypica, consisting of 7 principal and 2 intercalary hooks: 1 (1') 85-112 long, base $65-75$; 2 (2') 53-64 long, base 48-53; 3 (3') 40-48 long, base 45-50; 4 (4') 30-40 long, base 25-30; 5 (5') 24-30 long, base 16-20; 6 (6’) 25-69 long, increasing in size from apical towards basal armature; 7 (7') 20-26 long. Two intercalary hooks 32-37 long. Characteristic basal armature present (Fig. 15).

The surface of the bothridia is covered with tridigitate microtriches (Figs. 16-18), with filamentous microtriches interspersed (Fig. 18), and the rest of the scolex is covered with sausage-like villi with short filamentous microtriches (Fig. 19). On the surface of the bothridia, regularly arranged tufts of filamentous microtriches are present (Fig. 17). They occur between the tridigitate and short filamentous microtriches (Fig. 18). The tufts of microtriches surround a ciliated sensory receptor, consisting of a bulb which is connected with the distal cytoplasm by septate desmosomes, two electron-dense collars, a cilium with basal body, electron-dense vesicles and mitochondria (Fig. 19).

Remarks: The present specimens were identified as $O$. penetrans according to the descriptions of Palm et al. (1993) and Petersen et al. (1993). The scolex morphology and tentacular armature correspond between the specimens, though the worms from Indonesia had a larger scolex size. Palm et al. (1993) described $O$. penetrans from Tylosurus spp. obtained from Philippine waters as being up to 3780 long, and having a bulb ratio of 2.8-2.9. The present specimens are nearly twice as large, however, having similar scolex proportions $(1: 1.8: 1$ vs $1.1-1.3: 3.3-3.9: 1)$ and bulb ratios (2.4-2.8:1 vs 2.8-2.9:1). The tentacular hook forms and arrangement correspond. Thus, though having a larger scolex size, the specimens are identified as $O$. penetrans.

Shields (1985) summarised information on 15 species within the genus Otobothrium and described $O$. kurisi Shields, 1985, O. penetrans Linton, 1907 and $O$. pephrikos Dollfus, 1960 as being closely related. Palm et al. (1993) synonymised $O$. kurisi with $O$. penetrans and noted a high scolex variability within the species.
The present specimens lie, in scolex size, between the descriptions for $O$. penetrans and $O$. pephrikos (SL $=$ 7500 , bulb ratio 2.9). Dollfus (1969) described $O$. pephrikos as a similar species to $O$. penetrans, differing in basal hooks which Dollfus "assumed" Linton would have drawn if they had been there. The tentacular armature of $O$. pephrikos (Fig. 24), however, corresponds closely with that described for $O$. kurisi and $O$. penetrans as well as in the basal armature as indicated by Shields (1985, figs. 3, 5) and Palm et al. (1993, figs. 4A, 5A-B). Thus, O. pephrikos Dollfus, 1969 is considered a junior synonym of $O$. penetrans Linton, 1907.

Shields (1985) also described the surface ultrastructure of $O$. kurisi ( $=O$. penetrans). The author recorded a scolex surface covered with microvilli and a bothridial surface covered with tridigitate microtriches. However, the author did not detect sensory receptors found in the present study. This is the first record of the species from the East Indian Ocean and underlines the world-wide distribution pattern for $O$. penetrans in tropical and subtropical waters.

\section{DISCUSSION}

The present study contributes to studies of the trypanorhynch fauna of fishes from Indonesian coastal waters. Together with Kotorella pronosoma and Hornelliella annandalei, eight different trypanorhynch species have now been recorded from Indonesia. The identification of six species that had been earlier described from other localities within the world Oceans supports a cosmopolitan distribution for these species, as indicated for Tentacularia coryphaenae by Dollfus (1942), and for other tentaculariids by Palm (1999) and Palm and Walter (1999) as well as for Otobothrium penetrans by Palm et al. (1993). On the basis of only two studies in Indonesian coastal waters, the cestode fauna shows similarities to that of other Indian Ocean coasts, where Nybelinia africana, Nybelinia scoliodoni, T. coryphaenae and Dasyrhynchus magnus (related to D. thomasi) were found. However, further examinations on a larger scale are necessary before any conclusions can be drawn.

The surface ultrastructure documented for $T$. coryphaenae, D. thomasi and $O$. penetrans provides further insights into the species relationships within trypanorhynch cestodes. T. coryphaenae has a similar ultrastructural hook morphology and tentacular wall as that described for $N$. queenslandensis by Jones and Beveridge (1998), rather than that described for the eutetrarhynchid Trimacracanthus aetobatidis (see Beveridge and Smith 1988). The ultrastructure of the hook-like microtriches along the bothridial borders and of the remainder tegument also corresponds. This supports the placement of Tentacularia together with 
21

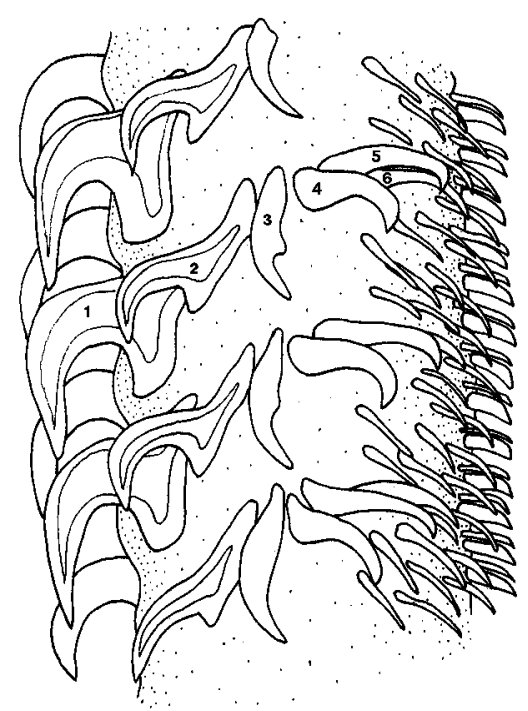

22

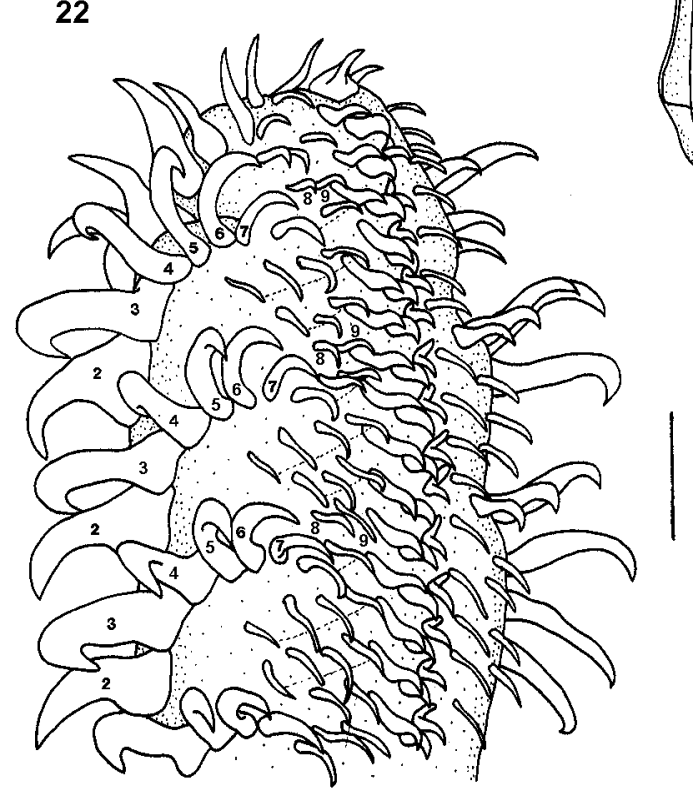

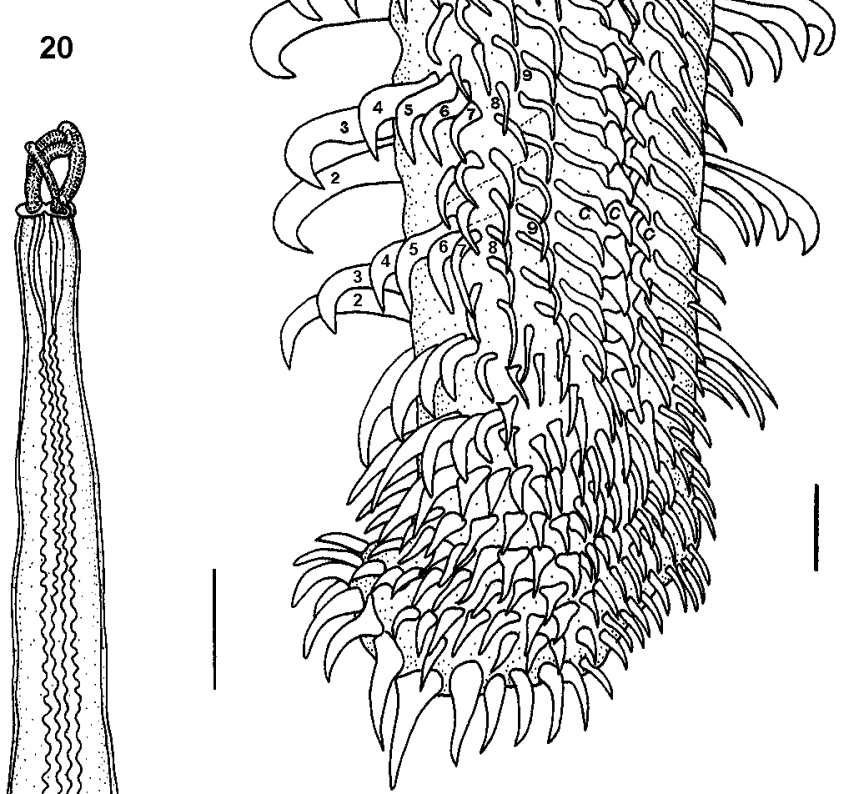

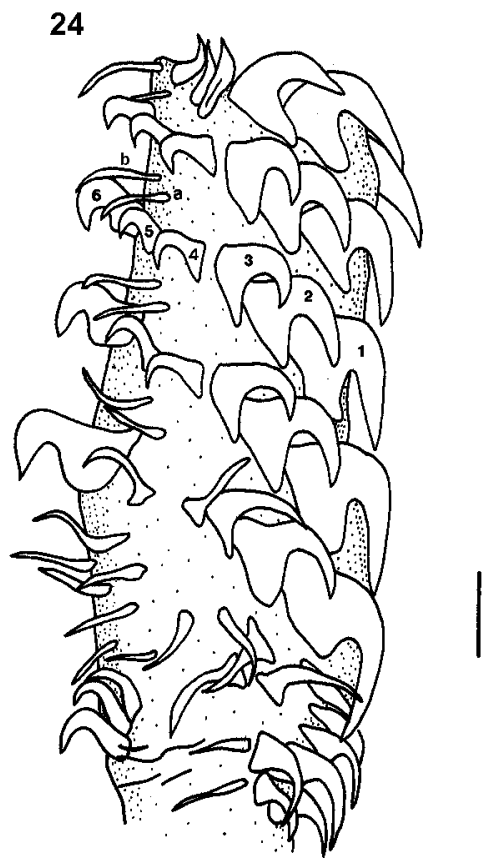

Figs. 20-23. Dasyrhynchus thomasi sp. n. from Psettodes erumei. Fig. 20. Scolex. Fig. 21. Bothridial tentacle surface, metabasal. Fig. 22. Bothridial/external tentacle surface, metabasal. Fig. 23. External tentacle surface, basal and metabasal. Fig. 24. Otobothrium pephrikos from Sphyrna zygaena. Basal and metabasal armature, bothridial tentacle surface. Abbreviations: a, b - intercalary hooks; c - chainette. Scale bars: Fig. $20=2$ cm; Figs. 21, $22=80 \mu \mathrm{m}$; Figs. $23,24=50 \mu \mathrm{m}$. 
Nybelinia within the same family, Tentaculariidae Poche, 1926. The presence of a split base of hook-like microtriches and of canaliculi within the hook-like microtriches might also occur in other tentaculariids, as they were not seen in all such microtriches of $T$. coryphaenae. Palm (1997b) proposed that hook-like microtriches observed in $N$. edwinlintoni might help movement. They might help to anchor the body in its position before the scolex pushes itself throughout the host tissue. A split base of the hook-like microtriches is helpful in firmly anchoring such microtriches within the distal cytoplasm.

Palm (1995) described the surface ultrastructure of Dasyrhynchus giganteus as having multi-fingered microtriches on the bothridial surface. The presence of similar microtriches on the bothridia of $D$. thomasi supports its placement in Dasyrhynchus. In contrast to other congeners, D. thomasi and D. magnus display a different scolex morphology by having distinctly different shaped small bothridia. However, the covering of the bothridia with multi-fingered microtriches might be similar between the species. This also supports the placement of Dasyrhynchus (=Pseudogilquinia) magnus within Dasyrhynchus and not in its own genus Pseudogilquinia (see Beveridge and Campbell 1993).

Palm et al. (1993) and Petersen et al. (1993) described $O$. penetrans from the musculature and body cavity of Tylosurus spp. obtained from the Visayan Sea, central Philippines. The specimens were variable in size, however, the pattern of the tentacular armature was the same. With the synonymy of $O$. pephrikos with $O$. penetrans, a large size range within the species becomes obvious. This variability might be due to several reasons such as the age of the plerocercus or storage and fixation (Palm et al. 1993). Palm (1999) described a wide variability in scolex morphology and size range within tentaculariid trypanorhynchs, and Campbell et al. (1999) found two different morphotypes of adult Par- oncomegas araya even within the same definitive host specimen, differing by a slender or robust scolex and a different number and size of mature and gravid segments. Other characters (the tentacular armature, scolex features, and reproductive anatomy) remained constant. Campbell et al. (1999) referred these differences to infrapopulation differences or different age, development or population density. It can be stated that the morphometrical data of scolex, armature and proglottids of trypanorhynch cestodes are often variable, making some identifications difficult. The tentacular armature, with characteristic hook forms and patterns, however, so far leads to a reliable species identification.

Palm et al. (1998) described retractile sensory receptors on the bothridial surface of the trypanorhynch Bombycirhynchus sphyraenaicum (syn. Patellobothrium quinquecatenatum), and attributed a mechano-receptory function to these structures. Such receptors have been also described from several other cestode species, and herewith with a similar regular arrangement also from $O$. penetrans. Such receptors seem to be common, though earlier studies on the scolex ultrastructure of $O$. penetrans by Shields (1985) and Palm et al. (1993) could not detect them. It seems as if the condition of the worms during fixation influence a projection of these receptors. Further comparative investigations are needed to identify them also in other trypanorhynch species to evaluate their usefulness as taxonomic or systematic tool.

Acknowledgements. I am grateful to Dr. Darnas Dana (Bogor Agricultural University, Indonesia) for his support during the study, and to R. Thomas for collecting the worms from Sumatra. I want to thank U. Mundt for her engagement at the TEM, and Dr. I. Beveridge (University of Melbourne, Australia) for critical comments on the manuscript. The study was supported through the German Academic Exchange Service (DAAD 98/22 736) and the German Research Council (DFG PA 664/3-1 and 3-2).

\section{REFERENCES}

ARTHUR J.R., MARGOLIS L., WHITAKER D.J., McDONALD T.E. 1982: A quantitative study of economically important parasites of walleye pollock (Theragra chalcogramma) from British Columbian waters and effects of post mortem handling on their abundance in the musculature. Can. J. Fish. Aquat. Sci. 39: 710-726.

BEVERIDGE I., CAMPBELL R.A. 1993: A revision of Dasyrhynchus Pintner (Cestoda: Trypanorhyncha), parasitic in elasmobranch and teleost fishes. Syst. Parasitol. 24: 129-157.

BEVERIDGE I., CAMPBELL R.A. 1996: New records and descriptions of trypanorhynch cestodes from Australian fishes. Rec. S. Aust. Mus. 29: 1-22.

BEVERIDGE I., CAMPBELL R.A. 1998: Re-examination of the trypanorhynch cestode collections of A.E. Shipley, J. Hornell and T. Southwell, with the erection of a new genus Trygonicola, and re-description of seven species. Syst. Parasitol. 39: 1-34.

BEVERIDGE I., SMITH K. 1988: Ultrastructure of the rhyncheal system of Trimacracanthus aetobatidis (Cestoda: Trypanorhyncha). Int. J. Parasitol. 18: 623-632.

BILQEES F.M., KHURSHID N. 1988: Surface ultrastructure of Tentacularia coryphaenae Bosc, 1797 (Cestoda: Trypanorhyncha) from the fish Cybium guttatum of Karachi coast. Proc. Parasitol. (Pak.) 5: 1-5.

BUSSIERAS J., ALDRIN J.F. 1968: Sphyriocephalus dollfusi n. sp., cestode Trypanorhyncha parasite de l'estomac du thon patudo, Thunnus obesus. Ann. Parasitol. Hum. Comp. 43: 645-653.

CAMPBELL R., MARQUES F., IVANOV V. 1999: Paroncomegas araya (Woodland, 1934) n. gen. et comb. (Cestoda: Trypanorhyncha: Eutetrarhynchidae) from the 
freshwater stingray Potamotrygon motoro in South America. J. Parasitol. 85: 313-320.

CHEN C.J., YANG R.T. 1973: Parasites of the yellowfin tuna in the waters southwest off Taiwan. Acta Oceanogr. Taiwanica 3: 181-198.

DOLLFUS R.P. 1942: Études critiques sur les Tétrarhynques du Muséum de Paris. Arch. Mus. Hist. Nat. (Paris) 19: 1466.

DOLLFUS R.P. 1960: Sur une collection de Tétrarhynques homeacanthes de la famille des Tentaculariidae récoltés principalement dans la région de Dakar. Bull. Inst. Fr. Afr. Noire, Ser. A, 22: 788-852.

DOLLFUS R.P. 1969: De quelques cestodes Tétrarhynques (Hétéracanthes et Pécilacanthes) récoltés chez des poissons de la Méditerranée. Vie et Milieu 20: 491-542.

DUBINA V.R. 1985: On the parasitofauna of Xiphioidea of the northwest area of the Indian Ocean. NOAA Tech. Rep. NMFS 25: 33-34.

FROESE R., LUNA S.M., CAPULI E.C. 1996: Checklist of marine fishes of Indonesia, compiled from published literature. In: D. Pauly and P. Martosubroto (Eds.), Baseline studies of biodiversity: The fish resources of western Indonesia. Manila-Philippines ICLARM 23, pp. 217-275.

HADIDJAJA P., ILAHUDE H.D., MAHFUDIN H., BURHANUDDIN, HUTOMO M. 1978: Larvae of Anisakidae in marine fish of coastal waters near Jakarta, Indonesia. Am. J. Trop. Med. Hyg. 27: 51-54.

HEINZ M.L., DAILEY M.D. 1974: The Trypanorhyncha (Cestoda) of the elasmobranch fishes from southern California and northern Mexico. Proc. Helminthol. Soc. Wash. 41: 161-169.

HUTOMO M., BURHANUDDIN, HADIDJAJA P. 1978: Observations on the incidence and intensity of infection of nematode larvae (fam. Anisakidae) in certain marine fishes of waters around Panggang Island, Peribu Islands. Mar. Res. Indones. 21: 49-60.

ILAHUDE H.D., HADIDJAJA P., MAHFUDIN H. 1978: Survey on anisakid larvae in marine fish from fish markets in Jakarta. Southeast Asian J. Trop. Med. Public Health 9: 48-50.

JONES M., BEVERIDGE I. 1998: Nybelinia queenslandensis sp. n. (Cestoda: Trypanorhyncha) parasitic in Carcharhinus melanopterus, from Australia, with observation on the fine structure of the scolex including the rhyncheal system. Folia Parasitol. 45: 295-311.

LESTER R.G.J., BARNES A., HABIB G. 1985: Parasites of skipjack tuna, Katsuwonus pelamis: fishery implications. Fish. Bull. 83: 343-356.

MEHL J.A.P. 1970: Two flesh parasites of barracouta (Teleostei: Gempylidae) from eastern Cook Strait. N. Z. J. Mar. Freshwater Res. 3: 241-247.

PALM H.W. 1995: Untersuchungen zur Systematik von Rüsselbandwürmern (Cestoda: Trypanorhyncha) aus atlantischen Fischen. Ber. Inst. Meereskd. Kiel 275, 238 pp.

PALM H.W. 1997a: An alternative classification of trypanorhynch cestodes considering the tentacular armature as being of limited importance. Syst. Parasitol. 37: 81-92.
PALM H.W. 1997b: Trypanorhynch cestodes of commercial fishes from northeast Brazilian coastal waters. Mem. Inst. Oswaldo Cruz, Rio de J. 92: 69-79.

PALM H.W. 1999: Nybelinia Poche, 1926, Heteronybelinia gen. nov. and Mixonybelinia gen. nov. (Cestoda: Trypanorhyncha) in the collections of The Natural History Museum, London. Bull. Nat. Hist. Mus. Lond. (Zool.) 65: 133-153.

PALM H.W., MÖLLER H., PETERSEN F. 1993: Otobothrium penetrans (Cestoda; Trypanorhyncha) in the flesh of belonid fish from Philippine waters. Int. J. Parasitol. 23: 749-755.

PALM H.W., OVERSTREET R.: New records of Trypanorhynch cestodes from the Gulf of Mexico, including Kotorella pronosoma (Stossich, 1901) and Heteronybelinia palliata (Linton, 1924) comb. n. Folia Parasitol. (in press.)

PALM H.W., POYNTON S.L., RUTLEDGE P. 1998: Surface ultrastructure of Bombycirhynchus sphyraenaicum (Pintner, 1930) (Cestoda: Trypanorhyncha). Parasitol. Res. 84: 195-204.

PALM H.W., WALTER T. 1999: Nybelinia southwelli sp. nov. (Cestoda: Trypanorhyncha) with re-description of $N$. perideraeus (Shipley et Hornell, 1906) and the synonymy of N. herdmani (Shipley et Hornell, 1906) with Kotorella pronosoma (Stossich, 1901). Bull. Nat. Hist. Mus. Lond. (Zool.) 65: 123-131.

PALM H.W., WALTER T., SCHWERDTFEGER G., REIMER L.W. 1997: Nybelinia Poche, 1926 (Cestoda: Trypanorhyncha) from the Mozambique coast with description of $N$. beveridgei sp. nov. and systematic consideration on the genus. S. Afr. J. Mar. Sci. 18: 273285.

PAPERNA I. 1991: Diseases caused by parasites in aquaculture of warm water fish. Annu. Rev. Fish Dis. 1: 155194.

PETERSEN F., PALM H.W., MÖLLER H., CUZI M. 1993: Flesh parasites of fish from central Philippine waters. Dis. Aquat. Org. 15: 81-86.

SENG L.T. 1997: Control of parasites in cultured marine finfishes in Southeast Asia - an overview. Int. J. Parasitol. 27: 1177-1184.

SEYDA M. 1976: On a case of a mass invasion of cestode Gymnorhynchus (Gymnorhynchus) gigas (Cuvier, 1817) larvae in muscles of Brama raii (Bloch, 1791). Acta Ichthyol. Pisc. 6: 59-65.

SHIELDS J.D. 1985: Surface morphology and description of Otobothrium kurisi new species (Cestoda: Trypanorhyncha) from a hammerhead shark, Sphyrna lewini. Int. J. Parasitol. 15: 635-643.

SOUTHWELL T. 1930: The fauna of British India including Ceylon and Burma. Cestoda. Vol. I. Today et Tomorrow's Printers and Publishers, New Delhi, 391 pp.

VIJAYALAKSHMI C., VIJAYALAKSHMI J., GANGADHARAM T. 1996: Some trypanorhynchid cestodes from the shark Scoliodon palasorrah (Cuvier) with the description of a new sp. Tentacularia scoliodoni. Riv. Parassitol. 13: 83-89. 
YAMAGUTI S. 1952: Parasitic worms mainly from Celebes. Part 1. New digenetic trematodes of fishes. Acta Med. Okayama 8: 146-198.

YAMAGUTI S. 1953a: Parasitic worms mainly from Celebes. Part 3. Digenetic trematodes of fishes II. Acta Med. Okayama 8: 257-295.

YAMAGUTI S. 1953b: Parasitic worms mainly from Celebes. Part 2. Monogenetic trematodes of fishes. Acta Med. Okayama 8: 203-256.

Received 14 October 1999
YAMAGUTI S. 1954a: Parasitic worms mainly from Celebes. Part 9. Nematodes of fishes. Acta Med. Okayama 9: 122133.

YAMAGUTI S. 1954b: Parasitic worms mainly from Celebes. Part 8. Acanthocephala. Acta Med. Okayama 8: 406-413.

YAMAGUTI S. 1954c: Parasitic copepods of fishes from Celebes and Borneo. Publ. Seto Mar. Biol. Lab. 3: 375398.

YAMAGUTI S. 1954d: Parasitic worms mainly from Celebes. Part 6. Cestodes of fishes. Acta Med. Okayama 8: 253374.

Accepted 2 February 2000 